\title{
Responsibilities of the Board of Directors in the Bankruptcy of the Limited Liability Company
}

\author{
By: \\ Padriadi Wiharjokusumo ${ }^{1)}$, \\ dan NovitaRomauli Saragih ${ }^{2)}$ \\ Tourism and Hotel Academy of DarmaAgung (APP), Medan ${ }^{1.2)}$ \\ E-mail: \\ knb.ministry76@gmail.com ${ }^{1)}$ \\ $\underline{\underline{\text { novitaromauli12@gmail.com }}}{ }^{2}$
}

\begin{abstract}
Article 97 paragraph (1) of the Company Law requires each member of the Board of Directors to be required in good faith and full responsibility to undertake the supervision of the company for the interests and business of the company. This implies the Board of Directors is liablefor each management and representation of the company in the company's framework in pursuing its purposes and objectives.This researchexaminesthe responsibilities of the board of Directors in the bankruptcy of the Limited Liability Company based on Law No. 40 of 2007. This research was conducted through a normative juridical approach.The data source of this research was gained from the library study. Then it was analyzed using the qualitative analysis which depicts and dissects the significant information.The conclusion of this research is thatthe responsibilities of the Board of Directors in Bankruptcy Limited Liability Company based on Law No. 40 of 2007 comprises 2 (two) aspects, in particular; civil liability and criminal liability.

Keywords: bankruptcy, civil liability, criminal liability.
\end{abstract}

\begin{abstract}
ABSTRAK
Pasal 97 ayat (1) Undang-Undang Perseroan Terbatas (UUPT) mewajibkan setiap anggota Direksi untuk melaksanakan itikat baik dan tanggungjawab penuh dalam melaksanakan pengawasan perseroan untuk kepentingan usaha (tujuan) perseroan. Ini menyiratkan Direksi bertanggung jawab atas setiap pengurusan dan perwakilan terhadap perseroan dalam rangka untuk kepentingan dan tujuan perseroan. Tujuan penelitian ini adalah untuk mengkaji tanggung jawab Dewan Direksi dalam kepailitan Perseroan Terbatas berdasarkan UndangUndang No. 40 tahun 2007. Penelitian ini dilakukan dengan pendekatan yuridis normatif yang bersifat deskritif. Sumber data penelitian ini diperoleh dari penelitian kepustakaan. Kemudian dianalisis secara kualitatif yang memaparkan dan menganalisis data penting. Kesimpulan penelitian ini adalah bahwa tanggung jawab Dewan Direksi dalam Perseroan Terbatas terhadap kepailitan berdasarkan Undang-Undang No. 40 tahun 2007 terdapat 2 (dua) aspek, yaitu; tanggung jawab perdata dan tanggung jawab pidana.

Kata kunci: Kepailitan, tanggungjawab perdata, pidana.
\end{abstract}

\section{INTRODUCTION}

Widjaja (2002: 8) points out that bankruptcy occurs within the company, resulting in the consequences to the
Directors do not have the right and authority to manage the company's assets. As a legal entity established with the plan and reason for running a company, 
bankruptcy may cause the company being unable to do its business activities. On the off chance that the company doesn't complete business activities, it will unquestionably cause losses. It is not only for the company itself,yet additionally the interests of the company's shareholders, and the interests of creditors that can't be completely paid from the sale of all the company's assets .

In this manner, in doing the company's business, there are at least 3 (three) interests which must be considered by the company's Directors as it is mentioned by Widjaja (2008: 76) namely:

1. Company interests;

2. The interests of the company's shareholders, particularly minority shareholders;

3. The interests of third parties related to the law with the company, specifically the interests of the company's creditors. Initially, under normal circumstances, the Directors acted in the interests of the company. In such a unique condition, that implies, if there is a loss to the company's assets, which is caused by the actions of the Directors that are wrong, negligent or have a conflict of interest or actions against the law, at the point the company is the only party entitled to claim the loss.

Since the company's assets are also the assets of shareholders, the law gives derivative rights to the company's shareholders who represent at least $1 / 10$ (one - tenth) of the total number of shares with voting rights can file a lawsuit, on behalf of the company, through a district court against members of the Board of Directors who due to their slip-ups or negligence have caused losses to the company. In the event that the disadvantaged in the interest of a minority shareholder, at that point, the privilege is given to individual shareholders.

The development of the company law shows that in bankruptcy, the Directors are no longer accountable to the company and shareholders solely, however to the company's creditors. Therefore, it also implies that fiduciary duty which initially only applies to the interests of the company has also shifted to become not only for the interests of the company and shareholders,yet additionally the interests of the company's creditors. The Company's lawsuit against Directors who violate, in the form of missteps or negligence or actions that have a conflict of interest or actions against the law that cause harm to the company is also subsequently given to creditors when the company is in bankruptcy.

Basically, bankruptcy can be filed by all types of creditors. There are no restrictions regarding the qualifications of creditors who can apply. As long as the creditor can prove that there is over one debt (obligation), and one of them has matured, at that point officially, the judge must declare the debtor to be bankrupt (Sunarmi, 2009: 38). Bankruptcy decisions result in bankruptcy assets being publicly confiscated. Bankruptcy assets are managed by the curator for the benefit of all creditors and debtors and the supervisory judge leads and oversees the implementation of the bankruptcy.

Based on the description in the problem's background above, the issue raised is: How is the Directors' responsibility in the bankruptcy of a Limited Liability Company based on Limited Liability Company Law No. 40 of 2007?

\section{LITERATURE REVIEW}

According to Tumbuan (2004: 253), the bankruptcy statement did not automatically cause the company being dissolved, only if one of the two incidents related to the company's bankruptcy as referred to in the Article 117 paragraph (1) c.1) and 2) the recent Limited Liability Company Law(Law No. 1 of 1995), the District Court could dissolve the company at the request of creditors. Therefore, the Bankrupt Company has not been disbanded, remains competent, and has the authority to take legal actions. He said that the bankruptcy of a legal entity did not reduce the authority and ability to act in its management. Bankruptcy does not touch the legal status of a legal entity, bearing in mind that bankruptcy is related to and only covers the assets of a legal entity. Legal 
entities as independent legal subjects remain capable of acting and therefore, basically the legal entities' organs still have their authority based on the law (rechtspersonenrechtelijkebevoegdheden).

$\mathrm{He}$ then concluded that it was clear that the Company's Board of Directors remained authorized to represent the company legally in carrying out any legal actions, both related to their rights and obligations, insofar as these actions did not constitute acts of conduct (beheersdaden) and acts of transfer (beschikkingsdaden) with respect to the assets of the company covered in the Company's assets(bankruptcy property).

The same opinion, also expressed by Jusuf (2004: 253), "It should be remembered that the curator does not replace the position of the Board of Directors / Commissioners in relation to the management of bankruptcy company assets. The curator is only responsible for the management and acquisition of company assets, outside the management of company assets, remains in the hands of the Directors and Commissioners."

He further said that the existence of a curator did not nullify the rights and obligations of the Board of Directors as the management which is an organ of the company, because the curator only took over the right to take care of and settle the asset of thebankrupt company, and did not take over other rights and obligations.

A different opinion was expressed by Sjahdeini (2002: 227), that in relation to the bankrupt company, the curator was in the same position as the Company's Board of Directors, because the curator replaced the position of the Company's Board of Directors after the company was declared bankrupt.

I agree with the opinion expressed by Fred BG Tumbuan and Amir AbadiJusuf, that the bankruptcy of the Company does not mean that the status of the limited liability company is lost. The existence of a Limited Liability Company legal entity means that the company's organs must also continue to exist. The legal status of a bankrupt company still exists before the company is liquidated, followed by liquidation. Even Article 142 paragraph (1) of the Company Law explicitly determines, namely: Dissolution of the company does not cause the company to lose the status of the legal entity until the liquidation is completed and the liability of the liquidator is accepted by the General Meeting of Shareholders (GMS) or court.

In Article 142 paragraph (2) the Company Law also determines: In the event of a liquidation of the company as referred to in paragraph (1):

1. must be followed by liquidation carried out by the liquidator or curator; and

2. The Company cannot take legal actions, except as necessary to clear up all of the company's affairs in liquidation.

From the two articles it can be interpreted that although the liquidation leads to a company being incapable of taking legal actions to clear its assets, namely in the process of liquidation, the company can still carry out legal actions in liquidation.

\section{RESEARCH METHODS}

The research performed in this study is normative juridical research. Juridical research is a study focused on assessing the application of norms or positive legal norms. Taking the term of Ibrahim (2008: $295)$ this kind of research is also called the term doctrinal research, ie research that analyzes the law written in the book and the law decided by the judge through the judicial process.

The nature of research in this study is an analytical descriptive. Analytical descriptive research is a study that describes, examines, explains, and analyzes a rule of law. In addition, this research is, however also prescriptive (problem solving).

1. Legal Material

The sources of data used in this study are secondary data in the form of primary legal materials, secondary legal 
materials, and tertiary legal materials, namely:

a. Primary Law Material

The primary legal material is a legal substance that is authoritative. The primary legal material consists of laws and regulations sorted by hierarchy such as laws relating to research.

b. Secondary Law Material

Secondary law material is a legal substance consisting of textbooks written by influential jurists, legal journals, scholars opinions, legal cases, jurisprudence, and recent symposium results related to the research topic. In this study, the secondary legal material used is in the form of relevant reference books, scientific papers, and related papers.

c. Tertiary Law Material Tertiary legal materials are the legal substance that provides guidance or explanation of primary and secondary legal materials in the form of general dictionary, language dictionary, newspapers, articles, internet.

2. Legal Material Collection Technique

Data collection method used in this research is Library Research. This literature research should obtain secondary data by studying the literature, legislation, theories, the opinions of scholars and other matters related to the subject matter.

3. Legal Material Analysis

The data obtained in the literature study of legal materials will be described and linked in such a way that it can be presented in more systematic writing to achieve the desired target in the form of an answer to the problems. The processing of legal materials is conducted deductively,drawing the conclusions of a general postulate (norms, rules, principles, etc.) for the concrete problem being faced.

\section{RESEARCH RESULT AND DISCUSSION}

The Directors' responsibility in the bankruptcy of a Limited Liability

\section{Company based on Limited Liability Company Law No. 40 of 2007}

\section{Civil Liability of the Board of Directors}

If the company is awarded as a legal entity, the company is recognized as an independent legal subject. If this is the case, then the question arises whether a company can be held accountable, isn't the company something abstract? The purpose of the abstract is that only the management of the company appears. If this is the case, then who can be held accountable for law, is it the management of the company? To answer this problem, there are several theories that discuss the existence of the company as a legal entity. One of them is organ theory which states that the company is represented by organs (its management).

This implies the company's liability can be claimed by the Directors who manage the company daily. But the thing that needs to be emphasized here is that technically the legal entity that is still being held responsible is the company as a legal entity, although in practice the company will be represented by the Directors. Whereas the owner of the company or shareholder has a responsibility as much as the capital he puts. As stated by R. Soekardono, that each company is only responsible for the capital inclusion in the company. Shareholders can be held accountable as long as shareholders use the company for personal gain.

This is regulated in Article 3 paragraph (2) of the Company Law:

a. Requirements of the Company as a legal entity have not been or have not been fulfilled;

b. The shareholders concerned directly or indirectly, in bad faith use the company solely for personal interests;

c. Shareholders are involved in illegal acts committed by the company; or

d. The shareholders concerned, both directly and indirectly, violated the law using the company's assets which resulted in the company's assets being insufficient to repay the company's debt.

Considering the limitation of the responsibilities of the shareholders, then as one of the requirements for the 
establishment of the company there must be capital that has been included in the company's Articles of Association. For this reason, why before a company is formally established, the deed of establishment and articles of association of the company must first be examined by the Minister of Justice and Human Rights.(See Articles 7, 8, 9 of the Company Law).

Basically, the actions of the Board of Directors can be the responsibility of the company as long as the act is under the authority stated in the articles of association of the company, then the act is considered as the company's act. The company's articles of association have outlined the authority and duties of the Board of Directors and even in certain legal actions, there must be approval from the Board of Commissioners. Therefore, the Board of Directors as a representative of the company obtain the power from the company itself. So, in this case, it applies the principle of exercising power is not to exceed what is given to them. If the Board of Directors takes actions outside the limits of their authority, the Board of Directors must also be held personally accountable(See Article 97 of the Company Law).

In understanding the accountability of Directors in civil law, it is also necessary to understand the meaning of acts that violate the Law or against the law in a civil manner (onrechtmatigedaad) related to the management of the company. Each member of the Board of Directors needs to understand the nature, meaning, and consequences of acts that violate the law and other matters related to the definition of acts that violate the law itself. To understand the nature and meaning of actions that violate the law, it is better to understand what is meant by "law" itself.

But the discussion of whether the "law" still leaves contradiction between legal experts. Until now, opinions about the need for a legal definition are still being disputed. Some states that the definition of law is needed, especially for those who are just learning the law, at least a preliminary guide to further study. With the formulation of the law, it can be known what is meant by the law so it can be avoided acts that violate or are often called against the law.
Rasjidi (1998: 29) points out that the existence of a legal definition will help those who are just learning the law. The study will show the way, which way to go. Raharjo(2000:3) sees the law as an embodiment of 1) certain values; 2) abstract norms and 3) tools used to regulate society.

Legal liability refers to the provisions of article 1365 and also article 1366 of the Civil Code is based on the starting point of actions for one's own actions, but besides that, there are still liabilities other than for one's own actions also because of the actions of others who violate the law. This is regulated in article 1367 of the Civil Code which states:

"A person is not only responsible for losses that are caused by his own actions, but also for losses that are caused by the actions of the people who are his dependents, or caused by goods under his supervision".

This provision is in line with the principle of vicarious liability. According to Hatrik (1996: 117) the law can determine vicarious liability, if there are things that happen, namely: a person can be held accountable for the actions of another person if someone delegates his authority according to the Act to others. Here requires a condition or principle of responsibility that is the delegation principle.

The appointment of members of the Board of Directors creates a legal relationship, issuingthe rights and obligations. Violations of "obligations" in such a way lead to "rights" demand. This is identical to the principle of legal liability which is always related to legal actions, both one's own actions and those of others under his responsibility. Therefore, the Board of Directors are not only responsible for his own actions, but can also be responsible for the actions of his attorney or subordinates who violate the law.

The principle of civil liability arises because there is a loss for one party because of the actions of another party. The loss referred to this case is in line with 
the understanding of Article 1246 of the Civil Code, namely:

1. In the form of costs, i.e. all expenses or expenses which have been spent temporarily;

2. In the form of losses, i.e. all losses because of damage to the creditors' belongings caused by the debtor's negligence;

3. In the form of interest, i.e. all the profits that should be the creditor's right If the debtor does not commit negligence.

The discussion of this civil law shows that all agreements made legally, both explicitly stated and not explicitly but because according to their nature required by propriety, customs or laws apply binding and must be carried out in good faith. Likewise, the management of the company by the Directors must be carried out in good faith and with full responsibility. This principle can be seen in Article 1338 of the Civil Code which states: All agreements made lawfully apply as a law to those who make them. The agreements cannot be withdrawn other than by agreement of the two parties, or for reasons which are stated by law to be sufficient.

Likewise, Article 1339 states: Agreements are not only binding for matters stated therein, but also for everything which by nature is an agreement, is required by propriety, custom or law.In civil law, besides Article 1365 of the Civil Code that has been described above, if in carrying out their duties a member of the Board of Directors violates the law, legal liability may be requested as stipulated in Article 1366 of the Civil Code which states: Every person is responsible not only for losses caused by his actions, but also caused because of negligence or for lack of caution.

Therefore, the principles of management of the company which are normatively regulated in The Limited Liability Company Law No. 40 of 2007, if violated, civil liability can be held. Civil liability by the Board of Directors is because of the mismanagement of the Company, or has committed violations and violates the principles of good faith that result in losses. Therefore, the principle of civil liability to the Board of Directors in managing the company is applying the principle of legal liability to compensate for damages or violations of the law.

\section{Criminal Liability of The Board of Directors}

In Article 155 of Law No. 40 of 2007 it is stated that the provisions concerning the responsibilities of the Directors and/or the Board of Commissioners for their faults and omissions stipulated in this law shall not reduce the provisions stipulated in the Law on Criminal Law. This implies the company's organs such as the Board of Directors and the Board of Commissioners maybe subject to criminal sanctions if the Board of Directors and the Board of Commissioners commit a criminal violation to conduct and control the company.

Criminal provisions refer to the Criminal Code (KUHP) which is spread in several provisions namely articles 226 and 396 to article 403 of the Criminal Code. Criminal provisions in the Criminal Code relating to the implementing of further bankruptcy property if the bankruptcy status has been decided by the judge (article 226, article 396, article 400 to Article 402 of the Criminal Code) and the cause of bankruptcy (Articles 396, 397, 399, 393, 403 Criminal Code).

According to Indonesian Criminal Code that criminal arrangements in the Criminal Code relating to bankruptcy are:

a. Any person who, declared to be in a state of bankruptcy or obvious insolvency, or as the spouse of a bankrupt with whom he is married, in community of goods, or as an executive or commissioner of a partnership, company, association or foundation, declared bankrupt, statutorily 
summoned to give information, either with deliberate intent stays away without valid reasons, or refuses to give the desired information, or with deliberate intent gives wrong information, shall be punished by a maximum imprisonment of one year and four months (Article 226 of the Criminal Code);

b. Any merchant who has been adjudged bankrupt or has been admitted to judicial cession of estate shall, being guilty of fraudulent bankruptcy, be punished by a maximum imprisonment of seven years, if he, in order to fraudulently abridge his creditors of his rights:

1st, either has invented or invents liabilities or has not accounted or does not account for assets, or has withdrawn or withdraws any property from the estate;

2nd-ly, has alienated any property either for nothing or obviously below the value;

3rd-ly, has favored or favors one of his creditors in a certain manner on the occasion of his bankruptcy or at a moment when he knew that his bankruptcy could not be avoided;

4th-ly, has not fulfilled or does not fulfill the obligations which rest on him in respect of keeping records pursuant to Article 6, first paragraph, of the Code of Commerce, and of keeping and producing books, documents and writings referred to in the third paragraph of said Article (Article 396 of the Criminal Code);

c. Any director or any commissioner of a limited liability company, Indonesian company on shares or cooperative society which has been adjudged bankrupt or of which the judicial settlement has been ordered, shall be punished by a maximum imprisonment of one year and four months (Article 397,398 of the Criminal Code);

d. Any director or commissioner of a limited liability company, Indonesian company on shares or cooperative society which has been adjudicated bankrupt or of which the judicial settlement has been ordered, shall be punished by a maximum imprisonment of seven years, if he, in order to fraudulently curtail the rights of the creditors of he limited liability company, the Indonesian company on shares or the cooperative society (Article 398 of the Criminal Code);

e. By a maximum imprisonment of five years and six months shall be punished any person who, in order to fraudulently abridge the creditors of their rights (Article 400 of the Criminal Code);

f. (1) Any creditor who joins an offer of a judicial accord as a result of an agreement either with the debtor or with a third party, whereby he has stipulated special benefits, shall, in ease of acceptance of the accord, be punished by a maximum imprisonment of one year and four months.

(2) The same sentence shall in the ease be applicable to the debtor or, if the debtor is a limited liability company, an Indonesian company on shares, a cooperative society or a foundation, to the director or commissioner who concludes such an agreement (Article 401 of the Criminal Code);

g. Any person who has been adjudged obviously insolvent or, without being a merchant, has been adjudged bankrupt, or has been admitted to judicial cession of estate, shall be punished by a maximum imprisonment of five years and six months, if he, in order to fraudulently curtail his creditors of their rights, either has invented or invents liabilities, or has not accounted or does not account for assets, or has withdrawn or withdraws any property from the estate, or has alienated any property for nothing or obviously below the value, or on the occasion of his obvious insolvency, cession of estate or bankruptcy, or at a moment when he knew that something or other could not 
be avoided, has benefited or benefits somehow one of his creditors (Article 402 of the Criminal Code);

h. Any director or any commissioner of a limited liability company, any Indonesian company on shares or any cooperative society who, except for the case in Article 398, has aided in or has given his consent to acts contrary to the Articles of incorporation, as a result of which the company or society becomes incapable of fulfilling its liabilities or has to be dissolved, shall be punished by a maximum fine of ten thousand rupiahs (Article 403 of the Criminal Code);

If the company is bankrupt, the criminal provisions will be imposed on the Directors and/ or the Board of Commissioners and even shareholders can not be separated from criminal provisions. If the bankrupt debtor is a company, the Directors and Commissioners can be charged with Article 398 and 399 of the Criminal Code if they do:

a. taking part in or approving acts that violate the company's articles of association and those actions result in heavy losses so that the company goes bankrupt.

b. taking part or approve loans with burdensome requirements intending to delay the bankruptcy of the company.

c. negligence in carrying out such bookkeeping is required by the Company Law and the Company's articles of association.

Even though Article 396, Article 397 and Article 403 of the Criminal Code regulate the causes of bankruptcy, they must meet the criminal criteria, namely with Article 396 of the Criminal Code (simple bankruptcy):

a. Expenditure beyond the limits of daily life / too wasteful; or

b. Borrowing money/capital with high interest, even though it is known that it does not help the bankruptcy; or

c. Can not show in full without the changes (graffiti or writings) as determined in Article 6 of the Indonesian Criminal Code.

Whereas if bankruptcy because of fraud in article 397 of the Criminal Code, namely: $1 \mathrm{st}$, either has invented or invents liabilities or has not accounted or does not account for assets, or has withdrawn or withdraws any property from the estate; 2nd-ly, has alienated any property either for nothing or below the value; 3rd-ly, has favored or favors one of his creditors in a certain manner on the occasion of his bankruptcy or at when he knew that his bankruptcy could not be avoided; 4th-ly, has not fulfilled or does not fulfill the obligations which rest on him in respect of keeping records under Article 6, first paragraph, of the Code of Commerce, and of keeping and producing books, documents and writings referred to in the third paragraph of said Article.

Thisimplies a bankruptcy is not a crime, although later in the bankruptcy process it will be possible for bankruptcy. Bankruptcy is related to acquiring debtors' assets to repay debts. Therefore, the legal subject that has been declared bankrupt is not the same as that he has committed a criminal act. To be declared as having committed a crime must fulfill the elements and criteria as stipulated in the Criminal Code as outlined above.

\section{CONCLUSION}

Based on the above discussion it can be concluded that the responsibilities of the Board of Directors in Bankruptcy Limited Liability Company based on Law No. 40 of 2007 comprises 2 (two) aspects, namely: civil liability and criminal liability. Civil liability by the Board of Directors is because of the mismanagement of the company or has 
committed violations and violates the principles of good faith that result in losses. Therefore, the principle of civil liability to the Board of Directors in managing the company is applying the principle of legal liability to compensate for damages or violations of the law. Whereas criminal liability as regulated in Article 155 of Law No. 40 of 2007, it is stated that the provisions concerning the responsibilities of the Board of Directors for their faults and omissions stipulated in this Law do not reduce the provisions stipulated in the Law on Criminal Law. This implies the company's organs such as the Board of Directors may be subject to criminal sanctions if they commit a criminal violation in terms to conduct and control the company.

\section{REFERENCES}

Hatrik,

Hamzah,AsasPertanggungjawabanK orporasi, Strict Liability dan Vicarious Liability, (Jakarta: Raja GrafindoPersada, 1996).

Indonesian, Criminal Code.

Ibrahim, Johny, TeoridanMetodologiPenelitianHuku mNormatif, Surabaya: Bayumedia, 2008, hal. 295.

Jusuf,

Abadi,

Amir, TanggungjawabDireksidanKomisari

$s$ Perusahaan Pailit, UndangUndangKepailitandanPerkembanga nnya:ProsidingRangkaianLokakarya TerbatasMasalahMasalahKepailitandanWawasanHuk umBisnisLainnya. (Jakarta: PPH, 2004).
Rasjidi, Lili, FilsafatHukum,

ApakahHukumItu?,

(Bandung:

RemajaRosdakarya, 1998).

SatjiptoRaharjo, IlmuHukum, (Bandung:

Citra AdityaBakti, 2000)

Sunarmi, HukumKepailitan, (Medan: USU Press, 2009).

PrinsipKeseimbanganDalamHukum Kepailitan di Indonesia, (Medan: PustakaBangsa Press, 2008)

Soekardono, R.,HukumDagang Indonesia, Jilid 1 (Jakarta:Rajawali, 1981).

Sjahdeini, Remy, Sutan, HukumKepailitan :MemahamiFaillissementSverordeni ngJuntoUndang-Undang No. 4 Tahun 1998. (Jakarta:Grafiti, 2002).

Tumbuan, Fred

$\mathrm{BG}$, PembagianKewenanganAntaraKurat ordan Organ-Organ Perseroan Terbatas, UndangUndangKepailitandanPerkembangan nya

ProsidingRangkaianLokakaryaTerba tasMasalah-

MasalahKepailitandanWawasanHuk umBisnisLainnya. (Jakarta: PPH, 2004)

Widjaja,

Gunawan, TanggungJawabDireksiatasKepailit an Perseroan, (Jakarta: PT. RajagrafindoPerada, 2002). 150 Tanya JawabTentang Perseroan Terbatas, (Jakarta: Forum Sahabat, 2008). 